\title{
ANALYSIS OF PROMISING BARLEY (Hordeum vulgare L.) LINES PERFORMANCE BY AMMI AND GGE BIPLOT IN MULTIPLE TRAITS AND ENVIRONMENT
}

\author{
KENDAL, E. $.^{*}-$ KARAMAN, M. ${ }^{2}-$ TEKDAL S. $^{3}-$ DOĞAN, S. $^{4}$ \\ ${ }^{I}$ Mardin Artuklu University, Department of Plant and Animal Production \\ Kiziltepe Vocational and Training High School, Mardin, Turkey \\ ${ }^{2}$ Muş Alparslan University, Faculty of Applied Sciences, Department of Plant and Production \\ Technologies, Muş, Turkey \\ ${ }^{3}$ GAP International Agricultural Research and Training Center, 21100 Diyarbakir, Turkey \\ ${ }^{4}$ Siirt University, Institute of Science and Technology, Department of Field Crops, Siirt, Turkey \\ *Corresponding author \\ e-mail: enver21_1@hotmail.com \\ (Received $21^{\text {st }}$ Jan 2019; accepted $28^{\text {th }}$ Feb 2019)
}

\begin{abstract}
The development of stable and adaptable new cultivars are based only on positive results obtained from the interaction between the genotype and the environment. Therefore, the study aimed to test the stability and general adaptability of promising barley lines in terms of grain yield and traits in multi-environments. For this purpose, twelve barley genotypes were used in the study. The trials were carried out with four replications in a random design at seven environments in years 2012-13 and 201314. The superior and stable genotypes were identified with GGE biplot and AMMI (Additive main effects and multiplicative interaction) models. The AMMI analysis showed that the major treatment sum of squares was affected by environments (80.6\%), GE (14.0\%) and genotypes (5.4\%), respectively. On the other hand, the first two principal component axes (PCA 1 and PCA 2) contributed to the complete interaction with $88.1 \%$, whereas, PCA 3 and PCA 4 axes only with $12.0 \%$. The GGE biplot indicated that G4 is adaptable for all environments, while Altikat, G2 and G3 showed specific adaptation to E1, E3 and E5, G6, G7 and G8 to E6, respectively. According to both techniques, G2, G3, G6, G7, G8 and Altikat were the best genotypes with high yield, whereas G4 was the best with high yield, and stable and general adaptation. The results of biplot indicated that G4 (ARUPO /K8755//MORA/3/CERISE/SHYRI//ALEL I/4/CANELA/5/HART-BAR) was recommended for release and it was released as HEVSEL in 2017. On the other hand; G7 and G6 were protected as genetic material to use as parent in breeding programs for yield stability and quality respectively.
\end{abstract}

Keywords: breeding, barley, stability, GEI, grain yield

Abbreviations: AMMI, Additive main effects and multiplicative interaction; AEA, average-environment axis; AEC, average-environment coordination; GE, genotype by environment interaction; GGE, G + GE; MET, multi-environment trials; PC, principal component; PCA, principal component analysis; E, environment; G, genotype; TGW, thousand grain yield; HW, hectoliter weight; PC, protein content; HT, time of heading; $\mathrm{PH}$, Plant height

\section{Introduction}

Barley (Hordeum vulgare L.) is the fourth most commonly used crop after wheat, rice and corn worldwide and this crop is more durable than other grains for stress conditions (drought, salinity, temperature stress), which is important in arid and semiarid regions based on rainfall grows (Vaezi et al., 2017). The grains of barley are used as animal feed, food and biodiesel as well as raw material in malt industries to obtain 
malt. Approximately $65-70 \%$ of the produced barley in the world is used as animal feed, $33-35 \%$ as malt in beer, whiskey and biodiesel production and $2-3 \%$ as human food in food production. The consumption of barley in Turkey $90-92 \%$ is used as animal feed and the rest of it as malting in brewing and food industry (Anonymous, 2019).

The potential of a genotype in any environment is determined by the effect of environmental $(\mathrm{E})$, genotype $(\mathrm{G})$ or interaction (GE or GEI) factors. Because the breeders need quite stable cultivars in different environmental conditions and main some traits for agronomic, new varieties must have reliable results in a wide range of environments (Solonechnyi et al., 2015). The reason for the basic differences in the performance of genotypes in wide environments is due to the interaction of the genotype with the environment (Kendal and Aktas, 2016; Neisse et al., 2018). Genotype environmental interaction (GEI) analysis is of primary importance, as is the case for other crops inn barley breeding and many other intermediate studies (Kilic, 2014).

The most effective method to predict G, GE and GEI effects is multiple environmental trials (METs). METs are the most appropriate method to select the best genotypes for any environment and to identify genotypes that keep their genetic potential in many different environments (Farshadfar et al., 2012). Since the data obtained from METs are quite high, it is difficult to interpret these data without graphs. Therefore, different models have been used recently by many investigators to evaluate the data obtained from studies conducted in different environments. At the beginning of these methods, AMMI and GGE biplot methods are used and the shapes obtained from these methods visually provide the breeders with very important facilities in terms of the performance of the genotypes (Mortazavian et al., 2014; Solonechnyi et al., 2018). The AMMI model provides more information to researchers about the stability of genotypes in terms of grain yield, while GGE biplot on the relationships between genotypes and properties (Mohammadi et al., 2016).

The aim of this study was to evaluate the multiple traits data obtained from the studies conducted with advanced barley lines in multiple environmental conditions with AMMI and GGE biplot models and to determine the most stable genotypes as registration candidates and to present the benefits of these models to the breeders.

\section{Materials and methods}

\section{Material}

Ten spring barley promising lines and two checks were evaluated in seven locations across 2012-2013 and 2013-2014 years. The introductory information of genotypes presented in Table 1 and the introductory information about locations presented in Table 2. Altıkat cultivar used in the study as control; because this cultivar was released in 2011 in research area. So, it is very stable among cultivars which used in research on grain yield. Because it is regional and majority barley growers prefer the 6 rows cultivar in this area. Şahin 91 cultivar used in the study as control; because this cultivar is national a cultivar, and it is facultative type and used in common in north part of region, because it is resistant to cold damage which is sometime happening in spring time. Therefore the genotypes compared with this cultivars for grain yield and other properties of traits). 


\section{Method}

The trials was carry out in a randomized block design with four replications and planting density was used 450 seeds in per $\mathrm{m}^{-2}$. Plot size was $7.2 \mathrm{~m}^{-2}$ in sowing time ( $6 \mathrm{~m}$ long $\times 1.2 \mathrm{~m}$ wide) planted at $20 \mathrm{~cm}$ spaced and composed of a total of 6 rows. Sowing of trials were done in October month and Harvest were done in June in both of season and across locations. The sowing dates and harvest dates in all locations are not very effective, because the harvesting time is dry usually and sowing were done after rainfall. The fertilizing percentages were used $60 \mathrm{~kg} \mathrm{~N}^{-1}$ and $60 \mathrm{~kg} \mathrm{P}^{-1}$ with planting and $60 \mathrm{~kg} \mathrm{~N} \mathrm{ha}^{-1}$ was used to each plots at tillering time for all plots. The chemical struggle was done against weeds in the period of 2-4 leaves in all locations and seasons. Harvesting was done using a Hege 140 harvester in an area of $6 \mathrm{~m}^{2}$ in each plot.

Table 1. The information's about genotypes, used in experiment

\begin{tabular}{|c|c|c|}
\hline Genotypes & Pedigree of genotypes & Spike rows \\
\hline G1 & $\begin{array}{c}\text { NK1272/Moroc 9-75/6/ VICTORIA/4/GL/COPAL/TERAN 78/5/ SHYRI/7/ } \\
\text { CUNH./3/.. SEA01 04-OS.0S-0SD-0SD-0SD-0SD-0SD-0SD-0SD }\end{array}$ & 2 row \\
\hline G2 & $\begin{array}{c}\text { ROBUST//GLORIA-BAR/COBAL/3/KASOTA } \\
\text { CBSS00M00027S.0S-0SD-0SD-1SD-0SD--0SD-0SD-0SD }\end{array}$ & 6 row \\
\hline G3 & $\begin{array}{c}\text { CABUYA/JUGL } \\
\text { CBSS00M00060S.0S-0SD-0SD-01SD-0SD-0SD-0SD-0SD }\end{array}$ & 6 row \\
\hline G4 & $\begin{array}{l}\text { ARUPO/K8755//MORA/3/CERISE/SHYRI//ALELI/4/ CANELA/5/HART-BAR } \\
\text { CBSS00M00098S.0S-0SD-0SD-1SD-0SD-0SD-0SD-0SD }\end{array}$ & 2 row \\
\hline Altikat & Arta/4/Arta/3/Hml-02//Esp/1808-4L (ICB96-0601-0AP-10AP-0AP) & 6 row \\
\hline G6 & $\begin{array}{l}\text { ARUPO/K8755//MORA/3/CERISE/SHYRI//ALELI/4/ CANELA /5/HART- } \\
\text { BARCBSS00M00098S.0S-0SD-0SD-2SD-0SD-0SD-0SD-0SD }\end{array}$ & 2 row \\
\hline G7 & $\begin{array}{l}\text { ARUPO/K8755//MORA/3/CERISE/SHYRI//ALELI/4/ CANELA/5/HART-BAR } \\
\text { CBSS00M00098S.0S-0SD-0SD-4SD-0SD-0SD-0SD-0SD }\end{array}$ & 2 row \\
\hline G8 & $\begin{array}{c}\text { RECLA 78/SHYRI } 2000 \\
\text { CBSS00M00122S.0S-0SD-0SD-4SD-0SD-0SD-0SD-0SD }\end{array}$ & 2 row \\
\hline G9 & $\begin{array}{l}\text { CUCAPAH/PUEBLA/7/ROBUST//GLORIA-BAR/COPAL/3/ TOCTE } \\
\text { /6/GLOR/... CBSS00M00206S.0S--0SD-0SD-5SD-0SD-0SD-0SD-0SD }\end{array}$ & 6 row \\
\hline Şahin 91 & YEA 1553-1/Eskişehir. & 2 row \\
\hline G11 & $\begin{array}{c}\text { TAPIR-BAR/PETUNIA 1 } \\
\text { CBWS00WM00056S.0S-0SD-0SD-1SD-0SD-0SD-0SD-0SD }\end{array}$ & 6 row \\
\hline G12 & $\begin{array}{l}\text { ROBUR-BAR/142-B//ASTRIX/SUTTER334.3/3/3CABUYA } \\
\text { CBSS00M00053S.0S- 0SD-0SD-2SD-0SD-0SD }\end{array}$ & 6 row \\
\hline
\end{tabular}

Table 2. Years, sites, codes, coordinate status of environment long term of precipitation

\begin{tabular}{|c|c|c|c|c|c|c|}
\hline Years & Sites & $\begin{array}{l}\text { Code of } \\
\text { sites }\end{array}$ & $\begin{array}{l}\text { Altitude } \\
(\mathrm{m})\end{array}$ & Latitude & Longitude & $\begin{array}{c}\text { Annual rainfall } \\
(\mathrm{mm})\end{array}$ \\
\hline \multirow{3}{*}{$2012 / 13$} & Diyarbakir & $\mathrm{E} 1$ & 496 & $36^{\circ} 97^{\prime} \mathrm{N}$ & $38^{\circ} 42^{\prime} \mathrm{E}$ & 680.6 \\
\hline & Adiyaman & E3 & 483 & $37^{\circ} 46^{\prime} \mathrm{N}$ & $40^{0} 56^{\prime} \mathrm{E}$ & 592.0 \\
\hline & Hazro & $\mathrm{E} 2$ & 895 & $38^{\circ} 15^{\prime} \mathrm{N}$ & $40^{\circ} 49^{\prime} \mathrm{E}$ & 743.9 \\
\hline \multirow{4}{*}{$2013 / 14$} & Diyarbakir & E4 & 496 & $36^{\circ} 97^{\prime} \mathrm{N}$ & $38^{\circ} 42^{\prime} \mathrm{E}$ & 356.7 \\
\hline & Adiyaman & E6 & 685 & $37^{\circ} 46^{\prime} \mathrm{N}$ & $40^{0} 56^{\prime} \mathrm{E}$ & 592.0 \\
\hline & Hazro & E5 & 895 & $38^{\circ} 15^{\prime} \mathrm{N}$ & $40^{\circ} 49^{\prime} \mathrm{E}$ & 743.9 \\
\hline & Ceylanpinar & E7 & 363 & $36^{\circ} 51^{\prime} \mathrm{N}$ & $40^{\circ} 20^{\prime} \mathrm{E}$ & 260.3 \\
\hline
\end{tabular}




\section{The described growing seasons 2012-2013}

After exiting the plants, the barley was developed with the cool weather and cold damage occurred in extreme winter days. Seasonal conditions were favorable for barley cultivation in the development period, but in March and April, partly due to arid history, the expected high yield was not obtained. Adiyaman location during the spring period to partially heat stress, Hazro location was exposed to frost damage in late spring. In Diyarbakir location, conditions were more favorable than other locations.

\section{The described growing seasons 2013-2014}

Seasonal conditions were negative in terms of barley cultivation in the development period and snowfall occurred on March 31, 2014, especially when the barley was in the period of stalking. Genotypes were exposed to drought in Ceylanpinar location. In the Adiyaman location, it was partially exposed to temperature stress and cold damage. In the Hazro location, frost damage occurred during the period of erasing. In Diyarbakir, cold stress were effective in March and heat stress after heading period. Therefore the grain yield of 2012-2013 season was suitable than 2013-14 growing season. The conditions of Ceylanpinar location is usually hard than other location, because the the total of rainfall of seasons usually is low (Table 2).

The protein content was measured in the NIT (Near-infrared transmittance) instrument.

\section{Statistical analysis}

The AMMI analysis was used to ranking of the genotypes based on grain yield and GGE biplot was used to see the relation hip between genotypes and tarits across seven environment and two years The AMMI model used as recommended by Verma et al. (2016), and GGE biplot were used as recommended by Yan and Thinker (2005), to identify the mega- environments and superior genotypes. Statistical analyzes of data were performed using JMP and GenStat 12 analysis programs.

The graph (1) introduced by AMMI analysis based on grain yield of across years, and other graphs (2-6) generated by GGE biplot, (2) the ranks genotypes based on stability in aceoss environments, (3) which-won-where/what of GT biplot based on across years, (4) the ranks genotypes based on ideal genotype, (5) the relationship between genotype by trait, (6) the relationship between environment by trait.

\section{Results}

The AMMI analysis showed that the major treatment sum of squares were effected by environments $(80.6 \%)$, GE (14.0\%) and genotypes (5.4\%), respectively (Tables 3 and 4). The major variation of yield explained by the circles showed that the environments varied and the majority of the variation in yield was due to environmental changes. On the other hand, the first two principal component axes (PCA 1 and PCA 2) distributed to the complete interaction $88.1 \%$, whereas, PCA 3 and PCA 4 axes only $12.0 \%$ (Table 5). The majority percent of multiplicative variance of the sum of the squares based interaction influenced by the first two PCA scores. 


$$
-5223-
$$

Table 3. The average yield performance at each E and over environments $\left(\mathrm{kg} \mathrm{ha}^{-1}\right)$

\begin{tabular}{|c|c|c|c|c|c|c|c|c|}
\hline Genotype & E1 & E2 & E3 & $\mathrm{E} 4$ & E5 & E6 & E7 & Mean of E. \\
\hline 1 & $5268 \mathrm{bc}$ & 4042 bd & $4810 \quad b$ & 3675 & 4299 ac & 3535 bd & 1751 & $3911 \mathrm{CD}$ \\
\hline 2 & $6310 \quad a$ & $4604 \mathrm{ac}$ & 4969 & 3467 & 4109 ac & $3056 \mathrm{de}$ & $1715 \mathrm{de}$ & $4033 \mathrm{BC}$ \\
\hline 3 & 6399 & $4494 \mathrm{ad}$ & $5163 \mathrm{ab}$ & 3150 & $4385 \mathrm{ab}$ & 3321 & 2033 & 4135 BC \\
\hline 4 & 6360 & $4775 \mathrm{ab}$ & $5008 \mathrm{ab}$ & 4617 & 4732 & 3967 & 2695 & 4593 \\
\hline Altıkat & $5748 \quad \mathrm{ab}$ & 4925 & 5925 & $3860 \mathrm{ad}$ & 4220 & $3977 \quad b c$ & 1159 & 4259 \\
\hline 6 & 4806 & $3746 \quad \mathrm{~d}$ & 3721 & $4288 \quad \mathrm{ab}$ & 5147 & 4867 & 2354 & $4133 \mathrm{BC}$ \\
\hline 7 & 5650 ac & $3896 \mathrm{~cd}$ & $5035 \mathrm{ab}$ & 4171 & 4295 ac & 3925 & 2847 & 4260 \\
\hline 8 & $5008 \mathrm{bc}$ & 4021 bd & $4710 \quad b$ & 4066 & 4571 & 4893 & $1891 \mathrm{~cd}$ & $4166 \mathrm{BC}$ \\
\hline 9 & 5494 ac & $4525 \mathrm{ad}$ & $5071 \mathrm{ab}$ & 2705 & 3488 & 2545 & 1518 & $3621 \mathrm{DE}$ \\
\hline Şahin & $4877 \mathrm{bc}$ & $4167 \mathrm{ad}$ & $4988 \mathrm{ab}$ & 2995 & 3478 bc & $4216 \quad a b$ & 1255 & $3711 \mathrm{DE}$ \\
\hline 11 & $5692 \mathrm{ac}$ & 4092 bd & 4646 bc & 3170 & 3292 & 3474 & 834 & 3600 \\
\hline 12 & $5313 \mathrm{bc}$ & 3746 & $5188 \quad \mathrm{ab}$ & 3689 & $4100 \mathrm{ac}$ & 3264 & 1760 & 3866 CE \\
\hline Mean & \begin{tabular}{|ll}
5577 & $\mathrm{~A}$ \\
\end{tabular} & $4253 \quad \mathrm{C}$ & $\begin{array}{lll}4936 & \mathrm{C} \\
\end{array}$ & 3654 & $4176 \quad \mathrm{CD}$ & $3753 \quad \mathrm{DE}$ & $1818 \quad E$ & \\
\hline $\mathrm{CV}(\%)$ & \begin{tabular}{|l|}
11.4 \\
\end{tabular} & 12.8 & 13.4 & 14.6 & 17.5 & 14.6 & 19.6 & 14.2 \\
\hline LSD & $92.1 *$ & $78.6^{*}$ & 94.8* & $77.5 * *$ & $104.8^{*}$ & $78.8 * *$ & $19.7 * *$ & \\
\hline
\end{tabular}

Table 4. The variance of AMMI analysis on grain yield of barley

\begin{tabular}{c|c|c|c|c|c}
\hline Source of Variance & DF & Sum of square & Mean of squares & F Ratio & Explained $(\%)$ \\
\hline Treatments & 83 & 500019991 & 6024337 & 18.48 & \\
Genotypes & 11 & 26817395 & 2437945 & $7.48^{* *}$ & 5.4 \\
Environments & 6 & 403068142 & 67178024 & $61.74^{* *}$ & 80.6 \\
Block & 21 & 22849272 & 1088061 & 3.34 & \\
G x E & 66 & 70134454 & 1062643 & $3.26^{* *}$ & 14.0 \\
Interaction PCA 1 & 16 & 43155999 & 2697250 & $8.27^{* *}$ & 65.0 \\
Interaction PCA 2 & 14 & 15320921 & 1094352 & $3.36^{* *}$ & 23.0 \\
Interaction PCA 3 & 12 & 4841983 & 403499 & 1.24 & 7.3 \\
Interaction PCA 4 & 10 & 3093078 & 309308 & 0.95 & 4.7 \\
Residuals & 14 & 3722472 & 265891 & 0.82 & \\
Error & 231 & 75323191 & 326074 & & \\
Total & 253 & 598192454 & 1785649 & & \\
\hline
\end{tabular}

Table 5. AMMI selections the first four genotypes for per environment and PCA scores

\begin{tabular}{c|c|c|c|c|c|c|c|c|c|c}
\hline Sites & $\begin{array}{c}\text { Mean } \\
\left(\mathrm{kg} / \mathrm{ha}^{-1}\right)\end{array}$ & Score & 1 & 2 & 3 & 4 & $\begin{array}{c}\text { PCA } \\
{[1]}\end{array}$ & $\begin{array}{c}\text { PCA } \\
{[2]}\end{array}$ & $\begin{array}{c}\text { PCA } \\
{[3]}\end{array}$ & $\begin{array}{c}\text { PCA } \\
{[4]}\end{array}$ \\
\hline E1 & 5577 & -25.89 & G4 & G2 & G3 & Altikat & -25.90 & 13.36 & 15.60 & 1.13 \\
E2 & 4253 & -20.52 & Altikat & G3 & G4 & G2 & -20.52 & -9.37 & 11.20 & -4.94 \\
E3 & 4936 & -26.34 & Altikat & G12 & G9 & G4 & -26.34 & -16.11 & -21.93 & 2.20 \\
E4 & 3654 & 16.59 & G4 & G6 & G8 & G7 & 16.59 & 4.24 & -3.67 & 22.48 \\
E5 & 4176 & 15.53 & G6 & G4 & G7 & G8 & 15.53 & 8.48 & 5.73 & 3.97 \\
E6 & 3753 & 29.19 & G6 & G8 & Şahin 91 & Altikat & 29.19 & -26.21 & 6.03 & -9.28 \\
E7 & 1818 & 11.43 & G7 & G4 & G6 & G3 & 11.44 & 25.59 & -12.96 & -15.56 \\
\hline
\end{tabular}

\section{The AMMI model showing Genotype x Environment means}

The AMMI method is interpreted as bi-directional, the genotypes and environment main effect indicate by $x$ axis and the effects of interaction indicate by $y$ axis (Fig. 1). 


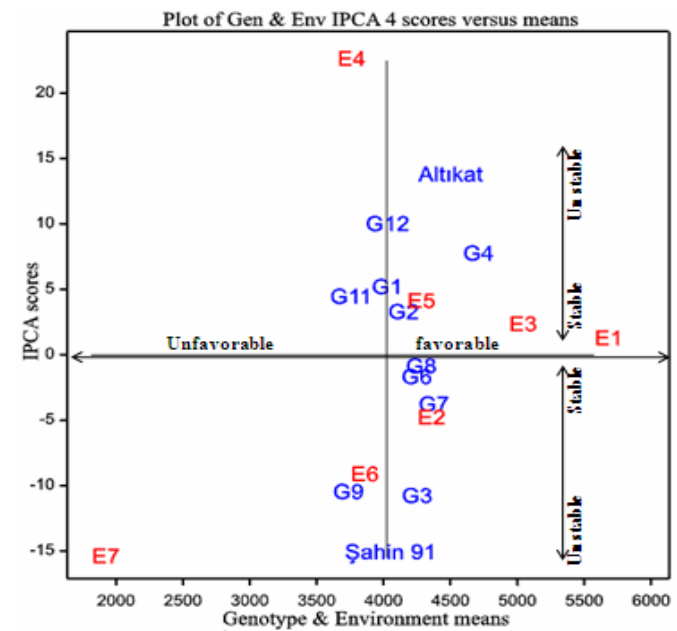

Figure 1. The AMMI model based on grain yield $\left(\mathrm{kg}_{\mathrm{g}} / \mathrm{ha}^{-1}\right)$ of genotypes $(G)$ in 7 environments $(E)$

The main effects of genotype and environment are seen along the $\mathrm{x}$-axis while the interaction effects are seen along the y-axis. On this figure; genotypes and environments are evaluated according to the mean (y axis) with stability (x axis). If the genotypes are close to the $\mathrm{x}$ axis, they are interpreted as stable, if they located the far from $\mathrm{x}$ axis it means that they are unstable. According to the AMMI analysis model, the genotypes showed a high variation and were found in different regions on the graph and the performance of the circles could be clearly seen. According to AMMI, E1, E2, E3 and E5 looking as high yielding environments, because these environments located upper on y axis, while E4, E6 and E7 looking as low yielding environments, because they located below of y axis. On the other hand, G2, G3, G4, G6, G7,G8 and G5 (Altikat variety) showed good performance, because of they located above on y axis (mean yield axis). It is believed that these genotypes were high yielding. But, G1, G9, G11, G12, G10 (Sahin 91) showed low performance, due to they located under on y axis (mean yield axis). Moreover, G4 is looking as high yielding genotype, but moderate stable because it was locate the far from $\mathrm{x}$ axis (stable line), while G8 is looking as stable, but this genotype is looking low yield potential than G4 genotype. The IPCA scores indicated that E1 could be recommended to tested genotypes, because of high yield potential of it (Table 5). According to Mirosavlievic et al (2014), the genotypes have small IPCA1 values are more stable, and similar outputs were recorded by Mohammadi et al (2013), in barley.

\section{The recommendation of genotype for environment}

The average grain yield of spring barley genotypes ranged from $3600 \mathrm{~kg} / \mathrm{ha}$ to $4593 \mathrm{~kg} / \mathrm{ha}$ in seven environments (Table 6). The genotype G4 was existence in the top of four environments. On the other hand, some genotypes estimated for special environments. For example; the genotype G6 dawn in the top genotype for E6, Altikat for E1, E3 and E5. Also, G4 can advise in the first to E1, E4 and the second to E5 and E7. The results of Table 5 and Table 6, showed that AMMI is an effective method to evaluate the perfect genotype for all environments or specific genotype for desirable environments. Moreover, the AMMI analysis is describe recommendations of correct genotype for special environment (Bantayehu, 2013). 


\section{The recommendation of environment}

The average yield of seven environments was changed from $1818 \mathrm{~kg} / \mathrm{ha}$ to $5577 \mathrm{~kg} / \mathrm{ha}$ of spring barley genotypes (Table 5). The AMMI analysis indicated that E1 is the best among test environments, followed E3 and E2.On the other hand, E7 is looking very poor among test environments, because the rainfall of this environment is very low. According to results of AMMI analysis showed that we can recommend the E1 to describe the top yield of genotypes, while E7 for describe the genotypes on drought conditions (Figure 1). Xu et al. (2014) reported that the GGE biplot is the best way to determine the best environment to tested genotypes.

Table 6. The traits value of average for twelve genotypes

\begin{tabular}{c|c|c|c|c|c}
\hline Genotypes & $\begin{array}{c}\text { Heading time } \\
\text { (date) }\end{array}$ & $\begin{array}{c}\text { Plant Height } \\
(\mathrm{cm})\end{array}$ & $\begin{array}{c}\text { Thousand } \\
\text { grain weight }(\mathrm{g})\end{array}$ & $\begin{array}{c}\text { Hectoliter } \\
\text { weight(g/l) }\end{array}$ & $\begin{array}{c}\text { Protein content } \\
(\%)\end{array}$ \\
\hline G1 & 98 & 83 & 38.1 & 74.2 & 13.2 \\
G2 & 96 & 89 & 33.7 & 71.4 & 11.1 \\
G3 & 97 & 83 & 40.1 & 72.2 & 12.1 \\
G4 & 96 & 84 & 39.1 & 74.3 & 12.0 \\
Alt1kat & 99 & 86 & 34.9 & 68.5 & 11.0 \\
G6 & 97 & 82 & 42.9 & 74.8 & 13.0 \\
G7 & 95 & 85 & 39.1 & 72.6 & 11.6 \\
G8 & 95 & 82 & 40.5 & 73.4 & 12.4 \\
G9 & 98 & 85 & 39.0 & 65.0 & 12.1 \\
Şahin 91 & 107 & 79 & 42.6 & 70.9 & 13.0 \\
G11 & 97 & 85 & 37.2 & 72.9 & 12.2 \\
G12 & 96 & 87 & 39.0 & 71.2 & 12.3 \\
\hline Mean & $\mathbf{9 7}$ & $\mathbf{8 4}$ & $\mathbf{3 8 . 9}$ & $\mathbf{7 1 . 8}$ & $\mathbf{1 2 . 2}$ \\
\hline
\end{tabular}

\section{Ranking genotypes based on stability and environment}

The ranking genotypes indicate the ideal and stable genotype in across environments, as showed in Figure 2.

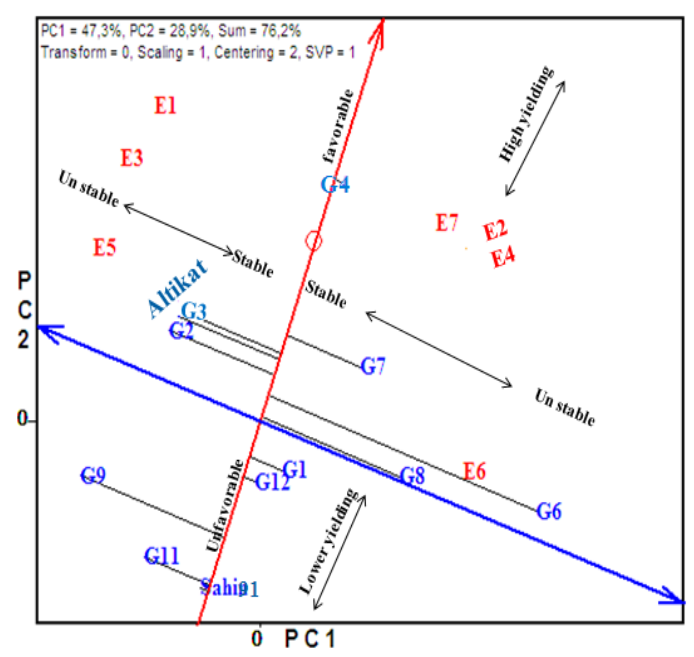

Figure 2. The rank genotypes based on stability 
The horizontal line with double arrow pointed the average of environment the upper of arrow points to higher mean yield through the environments, the vertical line with one arrow is ordinate the points the stability of genotypes across environments (Yan and Tinker, 2006). Thus, the genotype G4 with short genotype vector had both the highest mean yield and stability values, while Sahin 91 had low mean yield through across environment, but stable. On the other hand, G6 had above average yield, but unstable because of long genotype vector. The genotypes have large PC1 values mean that this genotype is high yielding and stable. The results of this study showed that G4 had wide adaptability for across environments, while G1, G9, G11, G12 and Sahin 91 for none environments. Some genotypes (G2, G3 and Altikat) showed special adaptability to special environments (E1, E3 and E5), G6, G7 and G8 to E6 (Fig. 2). Therefore, the ranking of genotypes are depend on their stability performance in across environments. Taheripourfard et al. (2017) reported that the GGE is good method to tested genotypes for multi-environment.

\section{Which-won-where/what of GE biplot based on across environments}

The GE biplot based on across season data is visualize the polygon of which-wonwhere/what. The figure divided by thick axis from center figure, and each zone separated by two thick lines is referred to as the "sector" and is indicated by numbers 1, 2, 3 etc., starting from the lower right part of the graph, and if the genotypes and traits located in the same sector it means that are closely related each other (Yan and Tinker, 2006; Dogan et al., 2016). Considering the Fig. 3 with this prediction; thick axis from center figure divide the biplot into five sectors. The environments (E1, E2, E5, E6, E7) with G4 down in the sector 2; G2 and Altikat with E3 in sector3; G1, G6 and G8 with E6 in sector1; while other genotypes did not relation with any environment. Consequently, G4 had high yielding at five environments (E1, E2, E5, E6 and E7), while G6 at E6. Therefore, the best genotype is definete by the best performance in mega-environments.

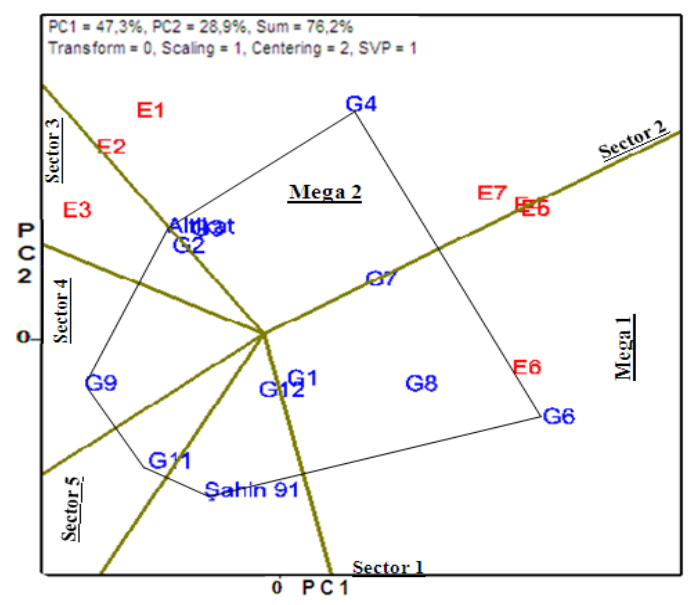

Figure 3. Which-won-where/what of GE biplot based on across season data

\section{The ranks genotypes based on ideal genotype}

The discriminating and representativeness of genotypes based traits are visualize the "ideal center" over the mean values of the environments and offers the opportunity to evaluate genotypes according to their proximity or distance to this center(Yan and Tinker, 2005; Oral, 2018). If the genotypes are located in the center, they are the most ideal, if they 
are located above the average vertical axis, but far from the center, it means that they are ideal, if they are located below vertical axis, it means that they are undesirable. Considering on this prediction the Fig. 4 explained that the G4 located center of AEA, and so, it is more desirable than other genotypes, while Sahin 91 is the poorest genotype, because it is located under mean axis. The term "ideal genotype" is meaningful only when associated with mean performance. According to Fig. 4, the G4 is highly "ideal", other genotypes (G2, G3, G7 G6, G8 and G5 (Altikat)) are desirable genotypes, and because of G4 took places in center of AEA and other genotypes took places on above averages yield axis, and so it means that they are just yielding for specific environments. On the other hand, G1, G9, G11, G12 and Sahin 91 are very poorest for average yield, so they are undesirable genotypes across environment. From this example, we can say that the ideal genotype (G4) is the best among genotypes for across environments.

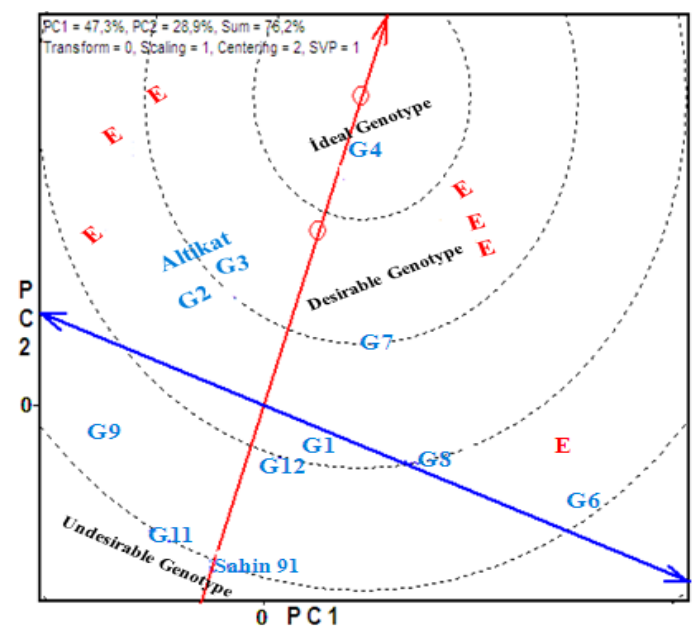

Figure 4. The ranks genotypes based on ideal genotype

\section{The relationship genotype by trait (quality) in seven environments}

The relationships between genotype by trait visualize the performance each genotype on traits (Fig. 5).

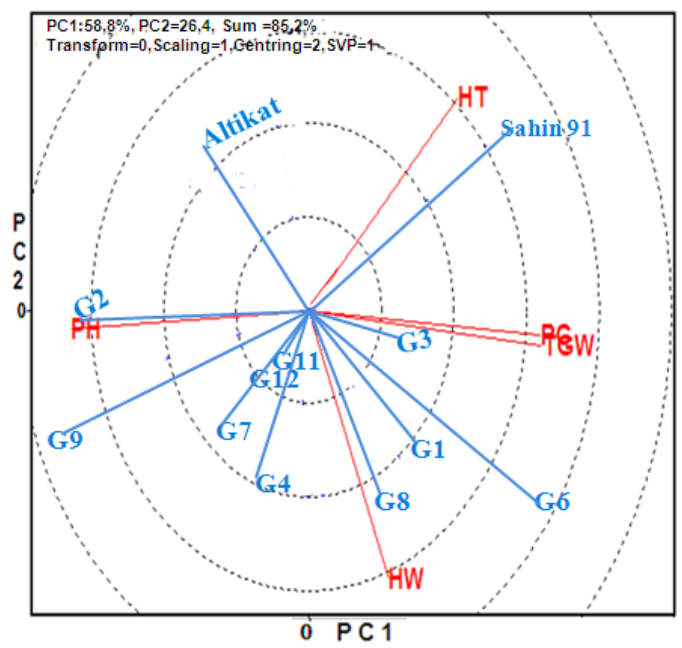

Figure 5. The relationship between genotype by trait 
A biplot such a graph to be interpreted bi-directionally has the following comments (Yan et al., 2000; Yan and Tinker, 2006; Kendal and Dogan, 2015). 1) The cosine of the angle between the vectors of the two properties approaches the Pearson correlation between them. Therefore, an angle of less than $90^{\circ}$ shows a positive correlation, an angle greater than $90^{\circ}$ shows a negative correlation and an angle of $90^{\circ}$ shows zero correlation. 2) If the vector of a trait is longer than other vectors, the variation of this trait on genotypes is higher than the other traits, if the vector length of any trait is very short than other traits vector then the variation of this trait is very low. 3) The angle between the vector of any genotype and any trait gives information about the state of the genotypes. If the angle is quite sharp and narrow indicates that the genotype is below of average for that trait if the angle is too large then the genotype is under. 4) The length of the vector of a genotype indicates the strength or weakness of the genotype for all trait profiles. Depend on these principles described in the GT biplot technique, the following observations can be made about Fig. 3. Considering the observations on this figure showed that there was positive correlation (the angel of vectors $<90^{\circ}$ ) among protein content (PC), thousand grain weight (TGW) and hectoliter weight (HW), whereas negative correlation (the angel of vectors $>90^{\circ}$ ) with plant height $(\mathrm{PH})$ and these three traits. Also, the relationship between genotypes and traits were observed. Therefore, G6 associated with PC, TGW and HW, while G3 with PC and TGW G2 with PH, Şahin 91 with heading time (HT). Because of the genotypes were positioned on these traits. Consequently, the biplot showed excellent discriminating to select special genotypes with special trait and results confirmed that barley parameters were affected by G, GE, and GEI as reported by (Dogan et al., 2016).

\section{The relationship between environments by trait (quality) of four genotypes}

The relationship between environment-trait showed in Figure 6 and Table 7. The information and explanations related to the identification of Figure 6 are already given in the upper section (3.5). The biplot showed that there was positive correlation between TGW and HW, between PH and HT, whereas negative correlation among PC and other traits except $\mathrm{PH}$.

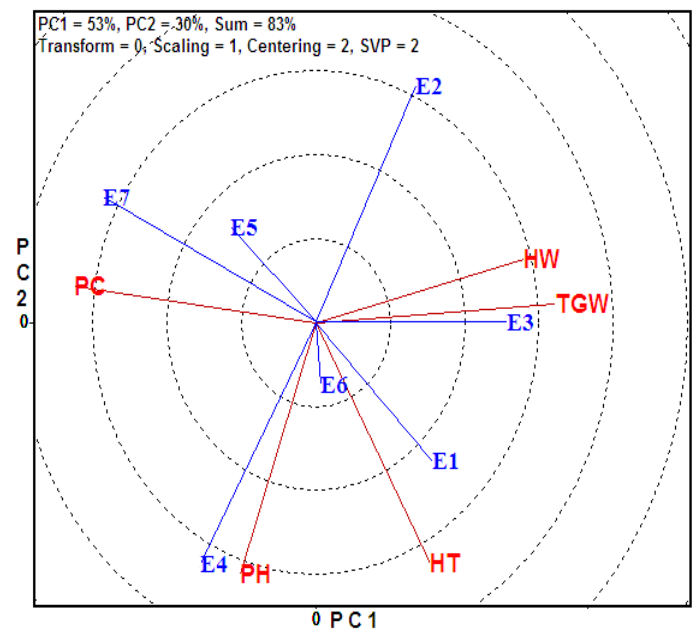

Figure 6. The relationship between environments by trait 
Also, the relationship between environments and traits were observed. Therefore, E3 associated with TGW, HW, while E1 with HT and E4 with PH and E5, E7 with PC. Because of these environments were positioned on definite traits. Consequently, the biplot showed excellent discriminating to select special environment with special traits and to work environments for recommendation special traits.

Table 7. The traits value of average over environments

\begin{tabular}{c|c|c|c|c|c}
\hline Environments & $\begin{array}{c}\text { Heading time } \\
(\text { date })\end{array}$ & $\begin{array}{c}\text { Plant Height } \\
(\mathrm{cm})\end{array}$ & $\begin{array}{c}\text { Thousand } \\
\text { Grain weight }(\mathrm{g})\end{array}$ & $\begin{array}{c}\text { Hectoliter } \\
\text { weight }(\mathrm{g} / \mathrm{l})\end{array}$ & Protein content(\%) \\
\hline E1 & 105 & 98 & 38.1 & 71.8 & 12.0 \\
E2 & 97 & 60 & 40.1 & 70.5 & 13.4 \\
E3 & 105 & 80 & 38.4 & 73.1 & 11.1 \\
E4 & 109 & 98 & 33.6 & 67.1 & 15.5 \\
E5 & 93 & 85 & 31.9 & 69.8 & 13.8 \\
E6 & 101 & 95 & 35.8 & 71.1 & 14.4 \\
E7 & 92 & 85 & 30.6 & 69.4 & 18.3 \\
\hline Mean & 100 & 86 & 35.5 & 70.4 & 14.1 \\
\hline
\end{tabular}

\section{Discussion}

The methodology of AMMI biplot approach have been reported to be a comprehensive and effective method since it classifies genotypes according to their levels in combination with target environments and graphically rank the genotypes with their strengths and weaknesses in different environments (Yan and Tinker, 2006). On the other, GGE biplot method allows breeders to establish an relations between genotype by traits or environment by traits (Dehghani et al., 2006; Stanisavlievic et al., 2013; Karami et al., 2018; Oral, 2018). The selection genotype by AMMI and GGE biplot method helps breeders to evaluate genotype on grain yield, and to seen the relations between genotype by traits or environment by traits (Sayar and Han, 2015; Dogan et al., 2016).

The AMMI analysis showed that the main effects of genotype $(\mathrm{G})$, environment $(\mathrm{E})$ and GE interaction are very important (Fig. 1 and Table 4). The results of AMMI showed that a large variation explained by environments $(80.6 \%)$, while a little variation by genotype effect (5.4\%). Therefore, the effect of the environment on the fluctuation and variation of the grain yield was found to be higher than the genotype effect and interaction. Many researchers have reported that they have achieved similar results in their AMMI studies (Bantayehu, 2013; Shukla et al., 2015; Kendal and Tekdal, 2016). According to Stanisavlievic et al (2013), majority percent of treatment variation explained by environment, while genotype and interaction effect is very low. On the other hand, the majority percent of multiplicative variance of the sum of the squares based interaction influnced by the first two PCA scores. Vaezi et al. (2017) reported that in the AMMI model in different parameters, because of stability analysis was performed using multiple IPCA numbers, and so it is better than stability analysis using the first IPCA score. Hense, the study showed that G4 is looking as high yielding genotype, but moderate stable, while G8 is looking as stable, but this genotype is looking low yield potential than G4 genotype. According to these explanations, it is possible to determine the best registration candidate for the Southeastern Anatolia Region of Turkey with AMMI method and this study can be used successfully for other regions, countries in different plants as well as. 
GGE biplot analysis establishes a framework for classifying target test environments that differ between genotypes which are stable and yielding (Fig. 2). The study showed that G4 is stable for all environment, while G6 is unstable for majoirty environments. If the effect of genotype in the variation $(\mathrm{G})$ is quite large $(47.3 \%), \mathrm{PC} 1$ scores will be highly correlated with G and PC2 $(28.9 \%)$ is controlled by GE interaction (Yan and Tinker, 2005; Kendal and Aktas, 2016; Kendal et al., 2016; Vaezi et al., 2017; Oral et al., 2018). GGE biplot gives an idea to evaluate the relationships between all circles (Fig. 3). The GGE biplot defines the relationships between all circles based on the general model of MET data, whereas the simple correlation coefficients define only the relations between the two environments (Farshadfar et al., 2013). In the study, there was positive and significant correlation among E1, E2, E3 and also E4, E5, E7 in whichwon-where graphical pattern. In fact, the GGE biplot polygon image is the best method used to determine the best genotype in every mega environment (Elakhdar et al., 2017). The study indicated that G4 is the best genotype for two mega-environment (Fig. 3), while G6 only for mega 1. The genotypes which are favorable discriminating and representative of across environments (Dehghani et al., 2006; Jalata, 2011; Kendal and Sayar, 2016).The study indicated that G4 is favorable genotype on discriminating and representative across test environments (Fig. 4). According to these explanations, it is possible to determine the best registration candidate for the Southeastern Anatolia Region of Turkey with GGE biplot method and this study can be used successfully for other regions, countries in different plants as well as. On the other hand, the results of the study showed that it was possible to make environmental-genotype relations, the stability of genotypes in all circles, the most ideal genotypes and mega environment in all circles with the figures formed by GGE biplot method.

\section{Conclusion}

The results of the study evaluated with AMMI and GGE biplot; the genotype (G), environmental (E) main effects and the and GE interaction effect was significant for tested advanced barley genotypes warm and warm-half environments of Turkey and other similar countries. The genotype (G4) showed best performance on grain yield among genotypes across environments, therefore this genotype was desirable in terms of high mean yield and stability. On the other hand; specific genotypes were appropriate for specific environments (G2-E5, G7-E2, G9-E6) and E1 was the best yielding. The result of study indicated that G4 is suitable to recommend for release and G7 desirable origin for yield stability and G6 valuable source for quality to use in barley breeding program. These three lines were obtained from ARUPO /K8755//MORA/3/CERISE/ SHYRI//ALELI/4/CAN ELA/5/HART-BAR hybrid. Depend on the results G4 was released as HEVSEL in 2017. On the other hand; G7 and G6 protected as genetic material to use as parent in breeding program for improve grain yield and quality, respectively. The multiple environment data can be evaluated by AMMI and GGE biplot analysis, because these two analysis methods allow a meaningful and useful summary of genotype performance across test environments.

\section{REFERENCES}

[1] Anonymus (2019): http://www.zmo.org.tr/genel/bizden_detay.php?kod=30125\&tipi=17 \&sube $=0$. 
[2] Bantayehu, M., Esmael, J., Awoke, Y. (2013): Additive main effect and multiplicative interaction analysis and clustering of environments and genotypes in malting barley. African J. of Agricultural Research 8(18): 1896-1904.

[3] Dehghani, H., Ebadi, A., Yousefi, A. (2006): Biplot analysis of genotype by environment interaction for barley yield in Iran. - Agronomy J. 98(2): 388-393.

[4] Dogan, Y., Kendal, E., Oral, E. (2016): Identifying of relationship between traits and grain yield in spring barley by GGE Biplot analysis. - Agriculture \& Forestry/Poljoprivreda i Sumarstvo 62(4): 239-252.

[5] Elakhdar, A., Kumamaru, T., Smith, K. P., Brueggeman, R. S., Capo-chichi, L. J., Solanki, S. (2017): Genotype by environment interactions (GEIs) for barley grain yield under salt stress condition. - Journal of Crop Science and Biotechnology 20(3): 193-204.

[6] Farshadfar, E., Mohammadi, R., Aghaee, M., Vaisi, Z. (2012): GGE biplot analysis of $\mathrm{G} \times \mathrm{E}$ interaction in wheat-barley disomic addition lines. - AJCS 6(6): 1074-1079.

[7] Farshadfar, E., Rashidi, M., Jowkar, M. M., Zali, H. (2013): GGE Biplot analysis of genotype $\times$ environment interaction in chickpea genotypes. - European Journal of Experimental Biology 3(1): 417-423.

[8] Jalata, Z. (2011): GGE-biplot Analysis of Multi-environment yield trials of barley (Hordeum vulgare L.) genotypes in Southeastern Ethiopia Highlands. - International Journal of Plant Breeding and Genetics 5(1): 59-75.

[9] Karami, E., Arshadi, A., Sartip, A., Zare, M., Rezabakhsh, P. (2018): Genotypes performance in relation to drought tolerance in barley using multi-environment trials. Agronomy Research 16(1): 521.

[10] Kendal, E., Dogan, Y. (2015): Stability of a candidate and cultivars (Hordeum vulgare L) by GGE biplot analysis of multi-environment yield trial in spring barley. - Agriculture \& Forestry/Poljoprivreda i Sumarstvo. - 61(4): 307-318.

[11] Kendal, E., Aktaş, H. (2016): Investigation of genotypes by environment interaction using GGE Biplot analysis in barley. - Oxidation Communications 39(3-I): 2433-2446.

[12] Kendal, E., Sayar, M. S. (2016): The stability of some spring triticale genotypes using biplot analysis. - The Journal of Animal \& Plant Sciences 26(3): 754-765.

[13] Kendal, E., Tekdal, S. (2016): Application of AMMI model for evaulation spring barley genotypes in multi-environment trials. - Bangladesh Journal of Botany 45(3): 613-620.

[14] Kendal, E., Sayar, M. S., Tekdal, S., Aktas, H., Karaman, M. (2016): Assessment of the impact of ecological factors on yield and quality parameters in triticale using GGE biplot and AMMI analysis. - Pak. J. Bot. 48(5): 1903-1913.

[15] Kilic, H. (2014): Additive main effect and multiplicative interactions (AMMI) Analysis of grain yield in barley genotypes across environments. - J. Agr. Sc. 20: 337-344.

[16] Mirosavlievic, M., Przulj, N., Bocanski, J., Stanisavlievic, D., Mitrovic, B. (2014): The application of AMMI model for barley cultivars evaluation in multi-year trials. Genetika 46(2): 445-454.

[17] Mohammadi, M., Noorinia, A. A., Khalilzadeh, G. R., Hosseinpoor, T. (2016): Application of GGE biplot analysis to investigate GE interaction on barley grain yield. Current opinion in agriculture 4(1): 25-32.

[18] Mortazavian, S. M. M., Nikkhah, H. R., Hassani, F. A., Sharif-al-Hosseini, M., Taheri, M., Mahlooji, M. (2014): GGE biplot and AMMI analysis of yield performance of barley genotypes across different environments in Iran. J. of Agr.Sci. and Tec. 16(3): 609-622.

[19] Neisse, A. C., Kirch, J. L., Hongyu, K. (2018): AMMI and GGE Biplot for genotype $\times$ environment interaction: a medoid-based hierarchical cluster analysis approach for high-dimensional data. - Biometrical Letters 55(2): 97-121.

[20] Oral, E. (2018): Effect of nitrogen fertilization levels on grain yield and yield components in triticale based on AMMI and GGE biplot analysis. - Applied Ecology and Environmental research 16(4): 4865-4878. 
[21] Oral, E., Kendal, E., Dogan, Y. (2018): Selection the best barley genotypes to multi and special environments by AMMI and GGE biplot models. - Fresenius Environmental Bulletin 27(7): 5179-5187.

[22] Sayar, M. S., Han, Y. (2015): Determination of forage yield performance of some promising Narbon Vetch (Vicia narbonensis L.) lines under rain-fed conditions in Southeastern Turkey. - Agr. Sciences 21: 78-92.

[23] Shukla, S., Mirshra, B. K., Siddiqui, A., Pandey, R., Rastogi, A. (2015): Comparative study for stability and adapt-ability through different models in developed high the baine lines of opium poppy (Papaversomniferum L.). - Ind. Crop. Prod. 74: 875-886.

[24] Solonechnyi, P., Vasko, N., Naumov, A., Solonechnaya, O., Vazhenina, O., Bondareva, O., Logvinenko, Y. (2015): GGE biplot analysis of genotype by environment interaction of spring barley varieties. - Zemdirbyste-Agriculture 102(4): 431.

[25] Solonechnyi, P., Kozachenko, M., Vasko, N., Gudzenko, V., Ishenko, V., Kozelets, G., Vinyukov, A. (2018): AMMI and GGE biplot analysis of yield performance of spring barley (Hordeum vulgare L.) varieties in multi environment trials. - Poljoprivreda i Sumarstvo 64(1): 121-132.

[26] Taheripourfard, Z. S., Izadi-Darbandi, A., Ghazvini, H., Ebrahimi, M., Mortazavian, S. M. M., Abdipour, M. (2017): Identifying superior barley (Hordeum vulgare L.) genotypes using GGE-biplot across warm and moderate environments under irrigated conditions in Iran. - Crop Breeding J. 7(2): 23-35.

[27] Vaezi, B., Pour-Aboughadareh, A., Mohammadi, R., Armion, M., Mehraban, A., Hossein-Pour, T., Dorii, M. (2017): GGE biplot and AMMI analysis of barley yield performance in Iran. - Cereal Research Communications 45(3): 500-511.

[28] Verma, R. P. S., Kharab, A. S., Singh, J., Kumar, V., Sharma, I., Verma, A. (2016): AMMI model to analyse GxE for dual purpose barley in multi-environment trials. Agric. Sci. Digest 36(1): 9-16.

[29] Xu, N. Y., Fok, M., Zhang, G. W., Li, J., Zhou, Z. G. (2014): The application of GGE biplot analysis for evaluating test locations and mega-environment investigation of cotton regional trials. - Journal of Integrative Agriculture 13(9): 1921-1933.

[30] Yan, W. L., Hunt, A., Sheng, Q., Szlavnics, Z. (2000): Cultivar evaluation and megaenvironment investigation based on the GGE biplot. - Crop Sci. 40: 597-605.

[31] Yan, W., Tinker, N. A. (2005): An integrated biplot analysis system for displaying, interpreting, and exploring genotype $\times$ environment interaction. - Crop Science 45(3): 1004-1016.

[32] Yan, W., Tinker, N. A. (2006): An Biplot analysis of multi-environment trial data; Principles and applications. - Canadian Journal of Plant Science 86: 623-645. 


\section{APPENDIX}

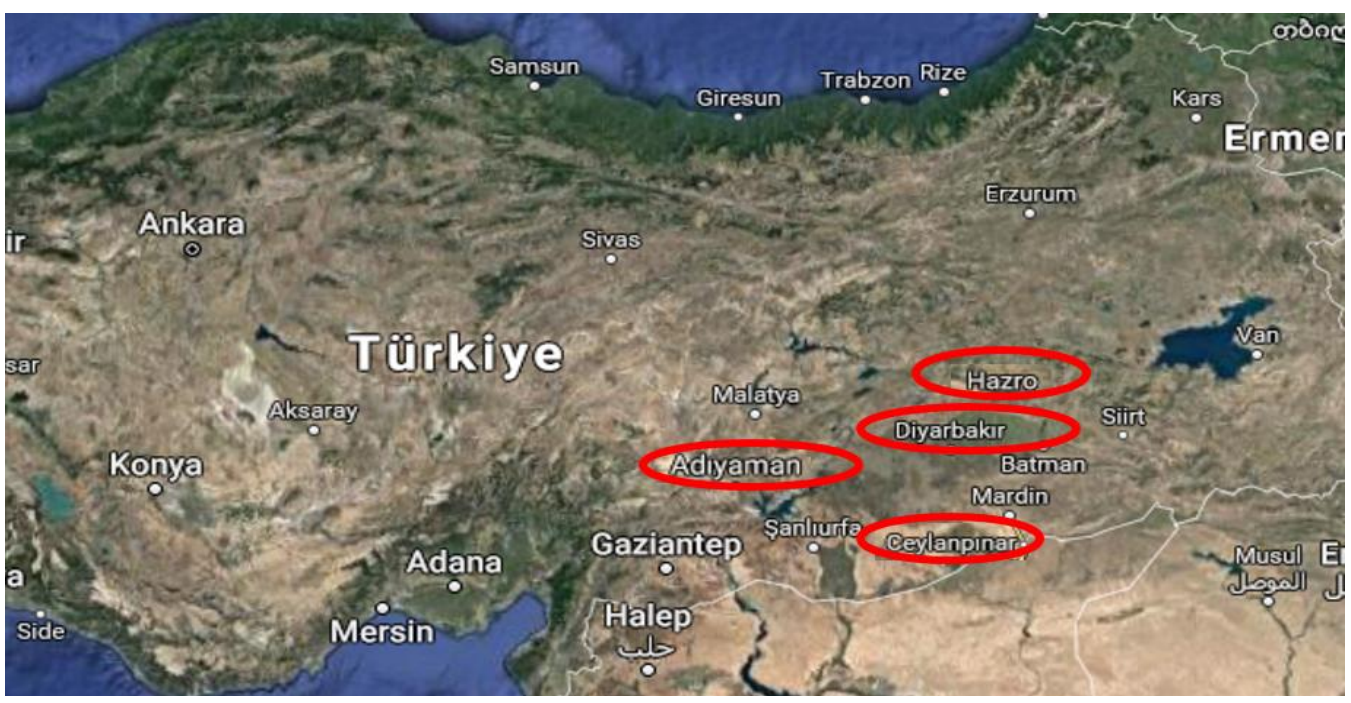

Picture 1. The locations of research was presented in Southeast Anatolia of Turkey

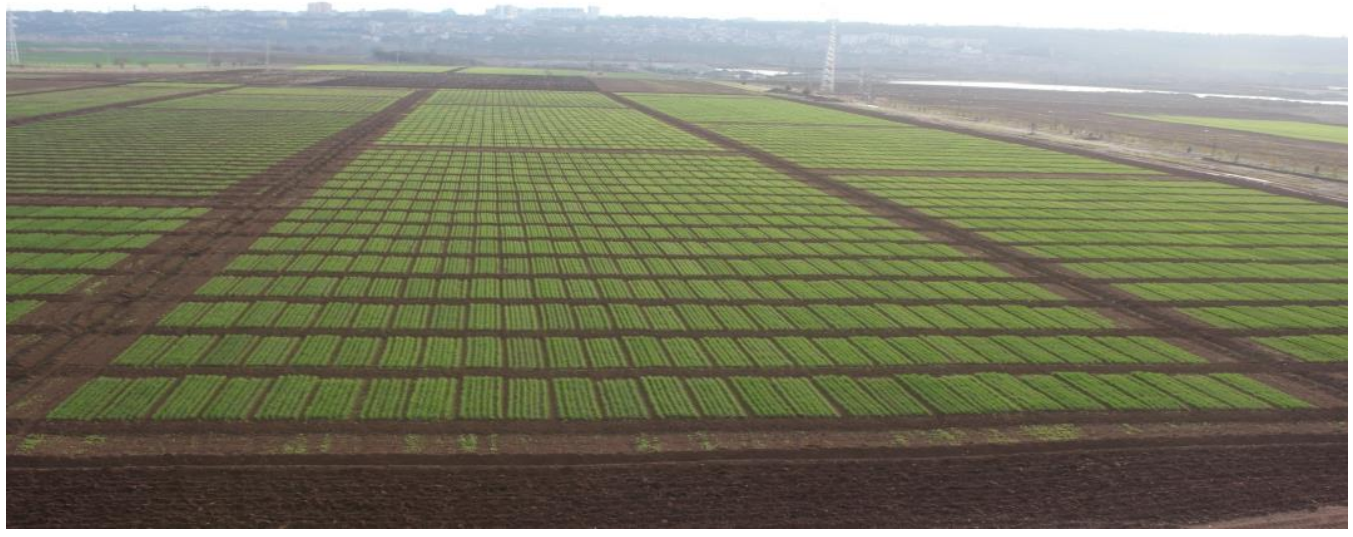

Picture 2. A photo of the genotypes in the trials

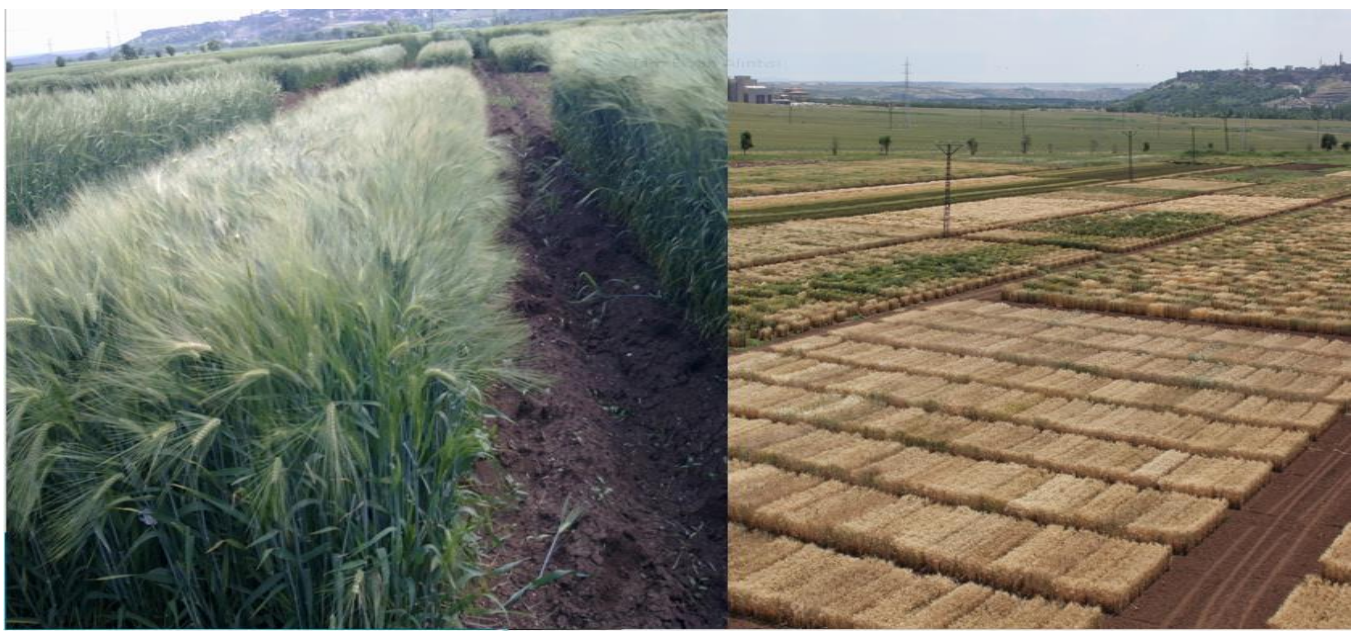

Picture 3. A photo of before and after maturity time of genoteypes in the trials 